\title{
MIDDLE EAST LINK OF TERRORIST THREATS FROM THE PERSPECTIVE OF PESANTREN IN INDONESIA: CASE STUDY IN THE AREA OF MALANG
}

\author{
Gonda Yumitro $^{1 *}$, Elfatih Abdullahi Abdelsalam ${ }^{2}$, Syaza Farhana Mohamad Shukri ${ }^{3}$ \\ ${ }^{1 *}$ Department of International Relations, University of Muhammadiyah Malang, Indonesia and a Ph.D. Student of \\ Political Science, International Islamic University, Malaysia; ${ }^{2,3}$ Department of Political Science, International Islamic \\ University, Malaysia. \\ Email: ${ }^{1 *}$ gonda@umm.ac.id, ${ }^{2}$ elfatih@iium.edu.my, ${ }^{3}$ syazashukri@iium.edu.my
} Article History: Received on $24^{\text {th }}$ March 2020, Revised on $14^{\text {th }}$ May 2020, Published on $26^{\text {th }}$ May 2020

\begin{abstract}
Purpose of the study: This article elaborates on the perspective of pesantren towards the Middle East link of the terrorist threat in Indonesia and their notion on the policies conducted by the Indonesian government, especially in the area of Malang.

Methodology: This research is qualitative research by in-depth interviews, literature reviews, and focus group discussion (FGD) collecting data methods. The objects of this research were several pesantren leaders from different backgrounds such as Al Irsyad, Hidayatullah, Muhammadiyah, the Muslim Brotherhood, Nahdatul Ulama (NU), and Salafi. The data were analyzed using Nvivo 12 Plus and discussed with various literature reviews to perform the finding.

Main Findings: The pesantren considers that increasing cooperation between state agencies and groups that are judged as having a link to sources for radical ideology in the Middle East would help minimize the problem of radicalism and the threat of terrorism in Indonesia, especially in the Malang area. Therefore, in assessing and deciding various policies on Islamic terrorism, the government needs to consider the Islamic discourse as not to be misled by public opinion.
\end{abstract}

Applications of this study: This study is helpful for the government to evaluate its policies to face the issues of terrorism by understanding the Middle East link of terrorism in Indonesia based on the perspective of pesantren. Moreover, ina terrorism study, this article can be a reference source to analyze the issues.

Novelty/Originality of this study: The growing terrorism in Indonesia is often associated with pesantren as these institutions are assumed to have the potency of supporting radicalism. Moreover, they have an ideological and network connection with the Islamic movements in the Middle East. On the other hand, pesantren is claimed to be a means of spreading peaceful Islam and is ready to cooperate with the government in handling the issue of terrorism in Indonesia.

Keywords: Middle East, Terrorism, Threat, Pesantren, Ideology, Movement, Government.

\section{INTRODUCTION}

Radicalism is an issue that has begun to emerge globally since 2001 after the World Trade Center tragedy on September $11^{\text {th }}, 2001$, followed by the publication of a thousand books and articles (Goodrich, 2002). After a while, America declared a global war on terrorism and attacked Afghanistan. In post-September $11^{\text {th }}$, the ideology of radical movements tends to be linked to terror activities of the Al Qaeda network. It was supported by the publication by Ayman Al Zawahiri, a senior ideologue of Al Qaeda, explaining the spirit and strategy of global jihad (Kilcullen, 2005). The continuous mass media coverage of the radical terrorist movement has made the issue of radical ideology widely discussed in various circles regarding the spread of networks and their influence on world terrorism activities.

Indonesia, as a country with a majority Muslim population, is often suspected as a fertile field for the development of radical ideology since some of the terrorist activities were carried out in this country (Tumanggor, 2007). Moreover, the events of Bali Bombings I (2002) and II (2005) increased world attention about the threat of terrorism in Indonesia. Many Islamic educational institutions such as pesantren and madrassah have become the focus of attention regarding their potential to spread radical ideologies through Islamic education. While on the part of the government, various elements continue to actively capture terrorist networks, radical ideology discourse, and issues that had influenced public discussion and attention. After the beginning of the Syrian civil war in 2011, the effect of radicalism has returned to the surface along with the rise of the Islamic State of Iraq and Syria (ISIS). The power of this movement was strongly significant due to its colossal controlling region, stretching from Diyala in Iraq to Aleppo in Syria in 2014 (Schmid, 2015).

The strengthening of ISIS in the Middle East was also followed by the enhancement of ISIS' influence in Indonesia. The ISIS movement has allegedly entered several regions in Indonesia. The data supports the existence of a small group of people who declare themselves to be part of ISIS in Indonesia, including in the Malang area, a city in East Java. Those people mostly have a connection with local people who have joined ISIS with their duties to transfer the radical ideology, recruit and train more Indonesians to join ISIS (Taufiqurrohman, 2015).

Therefore, the Malang area has been announced by the National Counter-Terrorism Agency (Badan National Penanggulangan Terorisme/ BNPT) as a red area in the case of terrorist threats. Its position as a tourism destination and 
education city makes it a strategic location for terrorist links to recruit their cadre and to arrange their activities. Its location and condition made the government unable to optimally control the movement of people entering and leaving the area.

Moreover, the existence of various pesantren in this region is often identified as having links with the development of radical ideology. Most of pesantren officially use Arabic as their language communication tool, connected with the Middle East Islamic movements and have many alumni continuing their studies in Middle East countries. Such conditions on one side became the reasons for the possibility of pesantren connection with the Middle East links of the terrorists. On the other hand, it becomes the potency for the stake-holders to collect more comprehensive information with experiences based on pesantren to understand the terrorist issues connected to the Middle East links.

At the same time, pesantren have often claimed to be peace-loving institutions and have trained and educated many scholars to spread goodness wherever they are. For pesantren, the teaching of terrorism is contrary to Islam, and even pesantren have some modalities to face the terrorism threat, such as spiritual, curriculum, kyai-santri relations, and social modalities (Yumitro et al., 2019). Therefore, this article clarifies the pesantren commitment to facing the issues of terrorism.

Based on that condition, the authors examine the perspective of pesantren leaders toward the Middle East link with the threat of terrorism in Indonesia, mainly related to the network of Islamic radical ideology and opinions on the deradicalization policy carried out by the government. More specifically, this article discusses the questions; (1) what the perspective of pesantren leaders toward the relations of terrorism and conflicts/events in the Middle East is; (2) how did the pesantren respond to the government policies on facing the issues of terrorism especially those related to the Middle East link.

\section{LITERATURE REVIEW}

In this part, the authors explain the crucial position of pesantren within the Indonesian societies and the connection between Indonesia and the Middle East, which have been started several centuries ago colored by trading and ideological relations.

As a Muslim-majority country, Indonesia is neither Hindu nor Christian. Pancasila proudly was proclaimed as its official and basic philosophical foundations of the country. Therefore, all existing ideologies should be compatible with Pancasila. Moreover, in Indonesia, there are at least three forms of education in this country, namely schools, madrasa, and pesantren (Jamil et al., 2019)

In terms of pesantren, the existence of this institution has emerged in Indonesia since before independence. However, after the reformation, the color of ideologies supporting the pesantren became more varied because of the rise influences of transnational movement after the declining power of Soeharto authoritarianism. The emergence of Indonesia as a new democratic and decentralized country following the demise of Soeharto opened a broader opportunity for various Islamic movements to exist in Indonesian society life (Jones, 2016).

Several pesantren, Al Mukmin Ngruki in Surakarta, Al Islam in Lamongan, and Azzaitun in Indramayu were reportedly involved in terrorism (Sodiq \& Astuti, 2019). Pesantren is considered as the source institution of Muslim scholars. Some students studying in pesantren were West's opposites and could not keep up with times. Such a view has been produced and disseminated by various media. Many people believe in pesantren's misleading images published in newspapers, televisions, and various internet sources since some media publish their views on pesantren without checking that the published news is trustworthy and has accountable evidence.

Following the influences of transnational movements toward the pesantren in Indonesia, some notions indicated that pesantren has a close connection with the emergence of radicalism and terrorism. This stigmatization indicates that pesantren is becoming more competitive as an academic institution for the development of radical ideologies (Malik, 2017).

Moreover, in terms of the ideological colors, many pesantren and Islamic movements in Indonesia have been influenced by the Middle East, including the ideology and movements of terrorism. Some of the transnational movements which exist in the Middle East are also available in Indonesia since they exist as transnational Islamic movements. Most of their characteristics are the same. However, in some aspects, they adapt to the local culture and condition in Indonesia. Several pieces of evidence depict that the connections are established between these groups and the Middle East global terrorist networks, such as al-Qaida (Lim, 2011).

For instance, Bruce Vaughn revealed that both ideas and founders of one of the radical organizations in Indonesia, namely Jama'ah Islamiah (JI), came from the Middle East, especially Saudi Arabia (Vaughn et al, 2005). This terrorist organization became famous over the world since 2001 because its members planned some attacks targeting American objects. Moreover, this group also endorsed women and children in some of its acts since they have been radicalized from their families $\underline{(\text { Osman, 2010) }}$ 
The organization Middle East link which was a fraction of Darul Islam, has a direct relationship with Al-Qaeda - an organization led by Osama bin Laden. The JI members, led by Hambali, were found to have been involved in two attacks in Bali (in 2002 and 2005) and also twice in Jakarta (in 2003 and 2009) (Sukma, 1998). The characteristics of the JI movement are also the same as Al-Qaeda, which is to attack the symbols of the United States or Western countries in general, which are considered to have oppressed Muslims around the world. Moreover, in terms of its ideology, financial, and cultural networks, it uses the same as Al Qaeda and even did more broader penetration and influences (Kilcullen, 2005).

Initially, the transnational Islamic movements tended to focus on international issues. Issues related to the war in Afghanistan against the occupation of the Soviet Union during the Cold War became a central issue for members of transnational Islamic groups such as JI. This condition was illustrated by the routine sending of JI members to Afghanistan to help Muslims fight the Soviet Union's occupation since 1985 (Mubah, 2012). However, after the Cold War ended and the Taliban regime ruled in Afghanistan from 1996, the orientation and locus of the JI network movement began to change. This was marked by internal divisions within JI, eventually forming two factions: the Hambali-led faction and the Abu Bakar Ba'asyir's faction. It was under Hambali's leadership that JI members became involved in a series of acts of terrorism with a plan to attack American symbols in Indonesia. While the Abu Bakar Ba'asyir faction still adhered to the General Guidelines for the Struggle of Jama'ah Islamiah.

Besides Jama'ah Islamiyah, the views of other transnational Islamic groups, such as the Hizb ut-Tahrir Indonesia (HTI), Muslim Brotherhood, Laskar Jihad and the Indonesian Mujahidin Council (MMI) also continue to clash with the moderate views of the majority of Muslims in Indonesia (Jurdi, 2008). Even though some of the movements are locally oriented, these groups are connected to international networks (Hamilton-Hart, 2005).

These groups primarily demand the application of Islamic law in a country that they think is secular (Oak, 2010). Moreover, the view emerges that Islam in Indonesia is not 'pure' Islam because it has been mixed with local customs, so there is a discourse to 'purify' Islam in Indonesia. Such notions have colored the characteristics of Laskar Jihad and MMI, which want to implement Islamic sharia in Indonesia (Harahap et al., 2019).

Furthermore, some of those transnational Islamic movements even want to re-establish the caliphate. Meanwhile, some others, such as the Islamic Brotherhood moves to create Islamic unity, a network for the creation of an integrated Islamic state (Arifin \& Rohmah, 2019).

The inclusion of ideas regarding the purification and application of Islamic sharia is inseparable from the role of students who have completed their education in Middle Eastern countries. They spread Islamic thoughts that are very Arabcentric through the Institute of Campus Propagation in various universities in Indonesia, hoping to purify the teachings of Nusantara Islam (Baskara, 2017).

From the brief description above, it can be seen that the flow of thought, from the Middle East to Indonesia correlates with the development of Islam in Indonesia and the rise of the issue of terrorism. The emergence of this current connection has begun hundreds of years ago, since the 15th century, where trade between Indonesia and the Middle East reached its peak. During that period, the Islamisation of the archipelago has started, after hundreds of years dominated by Hinduism and Buddhism. In addition to that, the process of Islamisation in the archipelago took place peacefully, without violence, as well as it accommodated local culture so that it became attractive for the indigenous population to embrace Islam (Azra, 2006).

Unfortunately, the regional issues of the Middle East change from time to time, depending on the context of thought and events. In the context of the Middle East after the Second World War, some issues emerged, such as the Palestinian liberation war, the Cold War, sectarian conflicts, and discourse competition among Muslims themselves in the region (Valbjørn \& Bank, 2012). Those characteristics of conflict are prone to be exported to Indonesia and thus influencing the locals. Some of the terrorist problems, like the emergence of ISIS, also influenced Indonesians since some of the local people joined this group, and even died in battle or suicide bomb (Jones, 2016).

Related to the issue of terrorism in the area of Malang, Ali Fauzi, an ex-combatant of terrorists in Indonesia, stated that the presence of terrorists in this region was inseparable from international and national networks. Some informants even said that terrorists who acted in planning or developing their networks in the area of Malang were mostly newcomers who did not understand the local culture of people in Malang. Their existence is only due to utilizing the strategic position of the region. Thus, military intelligence that the authors met stated that the arrival of the terrorist network in the area of Malang was a source of the problem, where they even try to damage the image of Muslims and pesantren in the region. This military person admitted that he had taken a sincere approach to various pesantren earlier, and did not find any pesantren in the area of Malang to teach radical ideology. Pesantren and Muslims, in general, are victims of acts of terrorist groups since terrorism are not the same as jihad in Islam (Jamil et al., 2019). 


\section{METHODOLOGY}

\section{Participants}

This study was qualitative research through in-depth interviews, literature reviews, and focus group discussion-based conducted in the area of Malang, consisting of three regions: Batu city, Malang city, and Malang district. The informants of this research mostly were the prominent persons in various pesantren, such as the head of pesantren and senior teachers, from different backgrounds of Islamic movements such as Al Irsyad, Hidayatullah, Muhammadiyah, the Muslim Brotherhood, Nahdatul Ulama (NU), and Salafism.

They were pesantren Hafsah binti Umar and pesantren Tengaran 7 (Al Irsyad), pesantren Al Izzah and pesantren Arrohmah (Hidayatullah), pesantren Al Munawwaroh and pesantren Faqih Usman (Muhammadiyah), pesantren Al Hikam and pesantren Tanwir Al Afkar (NU), Pesantren Al Umm and pesantren Darus Sunnah (Salafi). Therefore, twelve pesantren leaders with six Islamic movement backgrounds participated in the interview of this research.

\section{Instruments}

After the data has been compiled, the authors invited some political scholars and Islamic activists to discuss the finding of this research in Focus Groups Discussion. The collected data was then analyzed and classified to simplify the explanation of the research findings using Nvivo 12 Plus as an analyzing tool. The literature reviews used to strengthen the result of the data discussion.

\section{FINDINGS}

Based on the research conducted, this part discusses the pesantren perspective on terrorism, and it's Middle East link and their response toward government policies in tackling terrorism.

\section{Perspectives of Pesantren on the Relations between Terrorism and the Middle East}

The study of pesantren's perspective on the issue of terrorism threats was started by filtering the level of understanding of pesantren on this phenomenon. Regarding the questions on the topic of the development of radical ideology, most respondents saw a link between the problems of radical thinking in Indonesia and the Middle East events, both directly and indirectly. The relationship is directly related to the transnational nature of the radical ideology. At the same time, the connection is indirectly associated with the different events of the Middle East that affect public emotion in Indonesia, especially those who believe that conflicts in the Middle East are also religious issues.

The direct relations in terms of ideology can be seen from the relationship between Prosperous Justice Party (Partai Keadilan Sejahtera/PKS) and the Muslim Brotherhood in Egypt where the spiritual and intellectual development of PKS Indonesia was influenced a lot by the Muslim Brotherhood in the Middle East (Machmudi, 2008). According to available sources, PKS is a transnational manifestation of the Muslim Brotherhood, which aims to enter the government to influence the policies and regulatory systems to follow Islamic values. So, it can be said that PKS is ideologically connected with the Muslim Brotherhood in Egypt. Besides, the example of indirect relation is the reactive response of Indonesian people to the attacks and invasions of America and Israel in the Middle East, such as in Palestine, Afghanistan, Iraq, Syria, and others(Sageman, 2004). The form of community responses also varied, ranging from demonstrations and criticism, dialogue with the government and signatures on the petition, peaceful action, and raising funds for victims of the war, even joining jihadist groups in the Middle East.

When given the question of the relation between education and the spread of radical ideologies from the Middle East to Indonesia, pesantren leaders who are alumni of the Middle Eastern institutions agreed that education could be a medium for the spread of radical ideology, primarily through informal learning. However, opportunities for spreading radical ideology are relatively small through formal education at universities. They explicitly said that they never found any teachings of terrorism and radicalism informal education on campus. They claimed that there is a special place teaching radicalism, but not in the institution where they have studied.

According to the leader of NU pesantren, if the students do not have a substantial understanding of Islam and nationalism since they were still in Indonesia, there will be possibilities for them to go against the government because of the radical ideology they learned in the Middle East. An informant from the Muslim Brotherhood added that relations between Indonesia and the Middle East have inevitably contributed to the style of education in Indonesia, especially among pesantren. Therefore, the teaching from the Middle East was often brought and disseminated in Indonesia, including the issue which is connected to radicalism (Fealy, 2004).

However, the leader of the Muhammadiyah pesantren argued that radical ideology should not spread through education. He said that the government has a control mechanism as representative of the state in the field of religious affairs to review the contents of the curriculum and making the spirit compatible with the state's constitution and ideology. He assessed that ISIS is a transnational movement from the Khawarij group who tends to use violence in dealing with parties that are considered different from their beliefs. Moreover, another characteristic of khawarij is the judgment of other Muslims who have different perspectives with their group to be considered as un-Islamic and worse, 
as infidels through an act called takfir (Joseph \& Liow, 2014). If groups are trying to threaten the existence and unity of Indonesia, the government should undoubtedly prohibit it.

On the other hand, one of the leaders of the Salafi pesantren stated that it could not be denied that what happened in the Middle East, such as the case of Syria, has a connection with religious issues. From his point of view, the problem that occurred was due to a different understanding of Islam between Sunni and Shia groups in Syria. He even convincingly mentioned that what the opposition did was a defense of the Sunni group after being treated inhumanely by the Bashar Al-Assad regime. Especially among Sunnis, according to him, what is happening in Syria now is by what has been said about the atrocities of Shiites against the Sunnis.

Furthermore, the head of the Al Irsyad pesantren argues that what is happening in the Muslim world is more due to domestic problems faced by Muslims, such as ignorance, various difficulties experienced, including the setting of the parties concerned with the wrong image of Islam. The different information he obtained could be maintained for some reasons, including the fact that he had checked the data from different reading materials both printed and online, then had been discussed with significant figures who were gathered, and then they found patterns of events that were so that it can be concluded that way.

The head of Hidayatullah pesantren also conveyed a similar opinion. According to him, what happened in the Islamic world is a result of the weaknesses of current Muslims in all aspects, such as politically and economically. The problem is that many of them wish to become giants of the world, and so they do things that are beyond their capability. On the other hand, they do not fully implement Islamic values. For example, this can be seen from the efforts to distribute aids to several problematic regions in the Middle East, which turned out were also used for the person or group needs which are according to the policy should not be carried out. As for the teachings of Islam itself, according to him, it is a religion that spreads peace.

The leader of the Muslim Brotherhood pesantren stated that the violence identified with Islam was caused by at least some factors such as territory and natural resources. This shows that the real basis of the violence was not the teachings of Islam but rather the events that grew up in the Middle Eastern community due to various factors earlier. Islam itself is a religion full of grace for the universe and all humanity (Bayman, 2003). However, if someone has grown up in a harsh environment, has continued education in the Middle East with a harsh climate, then he has the potential to become a follower of radical teachings.

Almost all pesantren leaders who became informants in this study argued that radicalism is a way of conveying criticism in the form of resistance movements or resistance to injustice that has been committed by the state leadership or caused by foreign intervention. In this case, it is understandable that almost all informants considered that the Middle East conflict was not merely sourced from ideological problems. It is just that in its development, ideology became a political tool to unite the movement to become massive so that the conflicts that occur are very likely to become more widespread; they even created a domino effect within Muslim-populated countries, including Indonesia.

Therefore, they stated that the handling of the issue of radicalism became necessary, for it could threaten the security of the nation and state in Indonesia. Moreover, various radical groups are also developing in Indonesia. The leaders of the pesantren said that with the growing number of radical Islamic movements developing in Indonesia if the government does not implement the right policies, the conflicts similar to those in the Middle East would likely occur, or the number of terrorist networks and movements might increase in Indonesia.

\section{Pesantren Response towards Government Policies Against Terrorism}

In assessing government policies concerning the handling of education issues and radical ideologies, various opinions emerge, some of which were supportive while some others were critical of governmental policies. The head of the NU pesantren, for example, supports the government policy to impose sanctions on anyone involved in radical organizations by revoking their citizenship status. More than that, he provides an appreciation for the government that has conducted diplomatic cooperation with Middle Eastern countries related to the issue of radicalism.

The leader of the Muhammadiyah pesantren considered that the government had a great opportunity in dealing with issues of the Islamic world, including in the matter of radicalism since Indonesia is the largest Muslim country in the world. Therefore, Indonesia is often considered as a representative before the international society to solve various strategic problems in the Islamic world in international forums.

According to the head of the Muslim Brotherhood pesantren, so far what was done by the government by forming a friendship forum between the state clerics which was handled by the city government named Kesbangpol (National and Political Unity) was quite good. However, discussions need to be expanded and improved, primarily by establishing Islamic mass organization forums. According to him, in this case, the scholars also need to maintain their ideals, so that they are not manipulated to weaken the propaganda of Islam. Through various communications like this, different reactive actions taken by the authorities in dealing with the existence of radical groups in Islam can be eliminated.

He gave an example that the authorities should not treat the people by force. The government should be like a rattan, not like iron. In this case, according to him, a dialogue involving various elements of society to find the best solution to 
various problems is the best way. In terms of facilitating dialogue, according to him, the government should prepare people who understand the problem comprehensively. Therefore, the misunderstanding due to behavioral and speaking faults can be minimized.

The leader of the Hidayatullah pesantren also expressed a similar opinion. He said that violence is not the right way to solve the problem of radicalism in Indonesia. He believes that the most effective way to solve this issue is through education channels to broaden the mindset of students. Furthermore, he even reminded the government not to merely use the mass media as a reference in policy-making because there are often problems and misinformation in delivering data. For example, this can be seen from how the ISIS issue was raised in Indonesia, of which the society often cannot distinguish it from the ideology of other Islamic movements such as HT and the Muslim Brotherhood.

The leader of Al Irsyad pesantren stated that the government should collaborate with various moderate Islamic movements to deal with the issue of radical Islam. During this time, without collaboration and coordination with the government, various moderate Islamic movements would be running separately and less massively in their actions. While firmly, he stated that if possible, the government should ban the spread of radical Islamic movements in Indonesia. This policy might not be reasonable if the intelligence system in Indonesia is not fully developed. Besides, he argues that the government also needs to control and spread ideology through the internet as practiced in China, or it could be by strengthening entry checking at Indonesian airports and ports.

Muhammadiyah pesantren leaders conveyed the needs for the government to coordinate with various elements of society, including strengthening law enforcement. Likewise, he believes that formal education in pesantren is not problematic because the government can control or work together to find out the various curriculum used. Also, various activities carried out in the pesantren environment are not carried out in a closed manner, but they open themselves towards multiple stake-holders, including towards the government.

Another criticism of the government's policies so far is that the assessment of problems by the government tends to be late and not sustainable. Regarding the government's position, the critics argued that it is not yet optimal in using the government's media to build strong public opinion within the community. The idea of the leader of the Muhammadiyah pesantren was supported by the view of the leader of the Salafi pesantren. He said that if the government at least provided attractive, up-to-date, and comprehensive information on various issues of radicalism and the problems of Muslims, then he promised to use the government publications as the primary source in studying numerous cases among Muslims and Islamic world. Likewise, the head of the NU pesantren argued that Indonesia already has the potential to solve the problem of radical ideology with the presence of two large, moderate Islamic organizations, namely NU and Muhammadiyah. However, the government needs to utilize this potential optimally through various collaborative activities.

The pesantren leaders from different backgrounds found the MUI role also cannot be excluded because it has a strong legitimacy to disseminate their point of view to the public. At the same time, MUI has the power to monitor and evaluate the existence of various Islamic organizations in Indonesia in the context of their doctrine and ideology. Furthermore, the head of the Muslim Brotherhood considered that the government needs to coordinate with various elements of society, building a network to the lowest level. According to him, the socialization carried out by the community itself against the threat of radical ideology to other members of the community would be more effective in fortifying the effects of views that threaten the unity of Indonesia.

\section{DISCUSSION}

The data explained above has already given a picture of the transnational link of terrorism, and the connection of Islamism in the Middle East and radicalism. Moreover, some of the pesantren leaders from different backgrounds also have already conveyed their notions regarding government policies in facing terrorism. At this moment, the authors provide an analysis of their points of view.

First, based on the coding result, some words often emerged, such as Indonesia, pesantren, government, Middle East, terrorism, radical, and various Islamic groups. These words could be used to understand the mapping correlated to terrorism based on figure 1 .

From figure 1, pesantren perspectives in understanding the threat of terrorism connected to the Middle East mostly concern with the issues of movements, groups, data, perspective, policies, and radicals. Each of those issues connected with different emphasis.

Second, the informants have different levels of understanding in assessing the origin of transnational terrorism associated with the Middle East. These differences in perception are not only due to differences in experience and ideology but also because of differences in the sources of reading they have acquired. Some considered that education in the Middle East has relations with radicalism, but some believed that the two things are separate issues. This is understandable because each of the views represented the notions and interests of each group. 


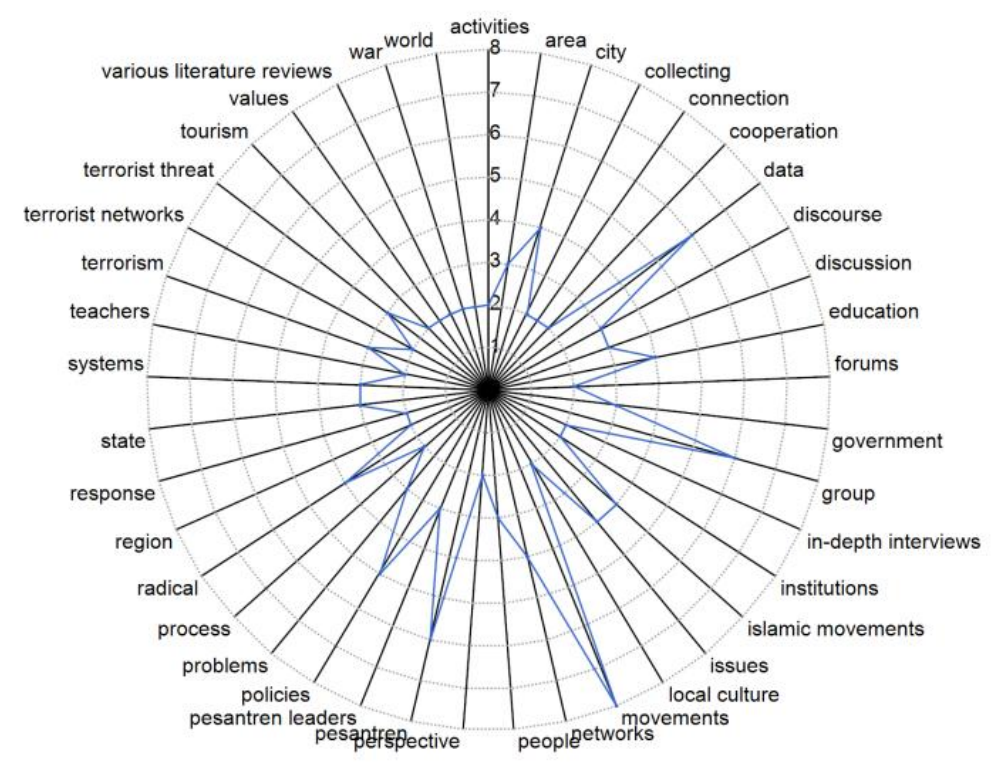

Figure 1: The Coverage of Issues on Middle East Terrorist Link Based on Pesantren Perspective

Source: Nvivo Plus Analysis Result, 2020

What the government needs to pay attention to is that people's views about radical groups also differ from one another. Even among groups, they discredit each other with extremist and terrorist labels. This opinion is most likely in line with some scattered writings related to the ideology of several transnational Islamic movements that also exist in Indonesia (Arifin \& Rohmah, 2019). The problem is that these opinions are often without direct confirmation with other Islamic movements that they accuse of being radical, for example, through dialogue. Therefore, these conditions have the potential to cause open conflicts among Islamic movements in Indonesia.

Regarding the connection of terrorism and the Middle East, all the informants from Nahdatul Ulama believed that the influences of the Middle East were negative, which means that the Middle East model of education influences the development of terrorist movements in Indonesia. However, other pesantren leaders have a positive response toward the Middle East education links. Therefore, these views influence the character of the Islamic spirit on both sides. Pesantren with NU background want to develop the local wisdom of Islam, which they call as Nusantara Islam. However, other pesantren from different movements tend to adopt the understanding of Islam from the Middle East perspective.

In this regard, all informants also agreed to the understanding that Islam entered Indonesia through a system of transfer of knowledge and culture from people to people contact. Moreover, all Islamic movements in the Middle East are available in Indonesia, such as Salafism, Muslim Brotherhood, Hizb ut-Tahrir, and Shiism (Arifin \& Rohmah, 2019). Usually, these movements spread and develop in Indonesia through the students studying in the Middle East. After studying at universities, some of them follow a variety of additional activities, such as joining talaqqi to the local imam.

In the end, some of them have grown to oppose industrialization and modernization. According to Islamic fundamentalists, the attitude of life of a Muslim under any circumstances and conditions must be under the traditional values and laws that exist in the Qur'an and the Sunnah of the Prophet. They believe that the only way where Islam could be leading again is when Muslims adhere to the spirit of jihad (Omar, 2011).

The influence of the Middle East is growing fast in Indonesia because of the large number of Indonesians studying Islam in the Middle East. Control over their existence, including over their understanding as learned in the Middle East, cannot be optimally carried out, especially since the presence of Indonesian students is not only in big cities considering the cost of living in cities is quite expensive. In the end, the spread of various Islamic teachings that are known to be radical even develops among them. However, this is often only a matter of perception due to cultural differences between Indonesia and the Middle East (Lim, 2011).

One example is concerning the way of speaking; the tone of speaking of Middle Easterners is different from Indonesians who are known to talk in a gentler and softer tone. The problem is, when a similar style is brought to Indonesia by those returning from the Middle East, this will be a problem because of the different speaking characteristics. This language and culture usually develop off-campus or outside formal education. If this condition develops without proper direction, then the pattern of relationships and informal learning will be an effective means of establishing radical movements in Indonesia. 
Another thing that can be associated with the growing proliferation of radicalism in the Middle East is because of the strong influence of the intrusive system of the major powers in the region (Brown, 1984). This condition led to the emergence of judgments from various radical groups that they needed to move into liberation. If they do not perform the concrete step, then it will cause Middle Eastern nations to be trapped in neo-colonialism that only benefits the powerful countries.

Third, regarding the policies that have been carried out by the government, some people have good access to various strategies that have been issued by the government even though its scope does not involve all elements. This can be seen, for example, from the views of some groups of people who appreciate government policies that will sanction anyone involved in radical organizations by revoking their citizenship status (Sopyan et al., 2019). Some communities also gave support and appreciation to the government after they learned that the government had made various efforts in handling the issue of radicalism.

The data indicated that most Islamic organizations have a positive image of the government policies in facing the issues of terrorism with Muhammadiyah and NU in the higher level of supports. Moreover, leaders of the Muslim Brotherhood and Salafi pesantren have the same level of the positive image toward government policies. On the other hand, Al Irsyad and Hidayatullah did not explicitly state their support but instead gave some comments for better government policies by collaborating with other actors and supporting the educational field.

For those who are not well informed of the programs and roles carried out by the government due to various factors, they also provide a variety of constructive criticism. This criticism, for example, can be seen from the demand that the government should go to the field to oversee a variety of materials delivered in lectures outside of campus. Also, there were still many opinions stating that the government needs to have a clear, measurable, and sustainable program related to their efforts in dealing with the spread of radical ideology in Indonesia, especially those with links from the Middle East (Posner, 2002). Moreover, the government is also demanded to provide more open and updated information concerning various issues arising to be used as references for the audience to understand the reality of what is happening.

Another serious issue that needs to be considered by the government in dealing with the problem of radicalism is the need for collaborative and coordinated steps involving all parties to face terrorist threats (Solansky \& Beck, 2009). Based on data collected in the field, all respondents demanded that they can live in a safe and peaceful atmosphere. This becomes the modality for the government to act because efforts to bring about peace will get support from the community.

Forth, in terms of methods to tackle terrorism, all pesantren from the various backgrounds give four fields which the government should be focused on, such as providing information center, improving law enforcement, enhancing education development, and focusing on collaborative works. These recommendations came from all pesantren, with Al Irsyad and Muslim Brotherhood recommending a collaborative way, and Hidayatullah supports the development of education. Furthermore, Muhammadiyah, NU, and Salafi demand the government to provide credible and valid information that can be referred by everybody who wants to know further about the information on terrorism issues. The picture of those ideas can be seen in figure 2 .

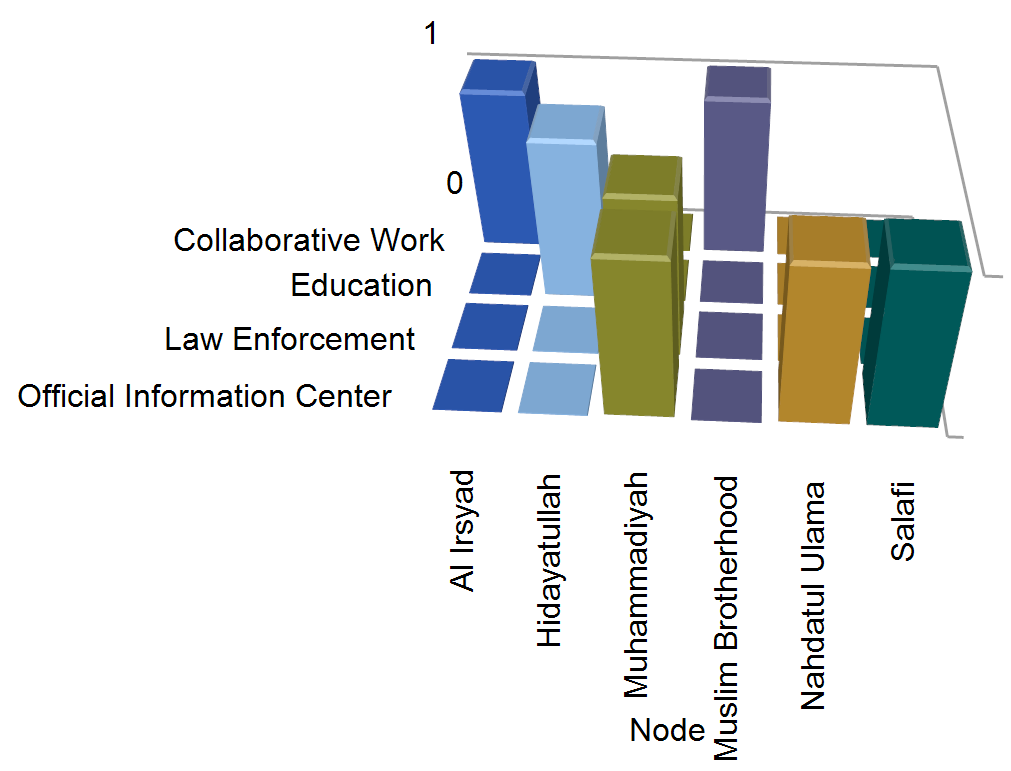

Figure 2: The Methods Facing Terrorism Offered

Source: Nvivo Plus Analysis Result, 2020 


\section{CONCLUSION}

The explanation above depicts that pesantren from different ideological backgrounds recognize that the problem of radicalism and the threat of terrorism in Indonesia, especially in the area of Malang, has direct or indirect relations with the Middle East. The relationship is specifically related to the transnational essence of radical ideology. At the same time, the link is indirectly related to the various Middle East events that affect the emotions of people in Indonesia, especially those who think Middle East conflicts are also religious issues. Furthermore, education can be a tool for extending radical ideologies, primarily through informal learning. Nonetheless, the possibilities of radical ideology through formal university in the Middle East are relatively limited.

Furthermore, nearly all Pesantren leaders who were informants of this study stated that radicalism is a way of conveying criticism or response to the injustice policies of the government or foreign intervention. In this case, almost all informants considered the Middle East war not only caused by political issues. It is comprehensible. Ideology has only become a political instrument in their growth to mobilize the mass drive to expand conflicts; even among Muslim populated countries, including Indonesia, they have developed a domino effect.

Regarding the policies of the Indonesian government, pesantren leaders have a different perspective, some give positive appreciation, and others criticize the policies on facing the issues of terrorism. Therefore, the government needs to evaluate its policies based on those views to produce a better and more effective and appropriate solution for the issues of terrorism.

\section{LIMITATIONS AND STUDY FORWARD}

This article has discussed at the local level in Malang regarding the Middle East link connected to terrorism in Indonesia. Therefore, in the future, the authors plan to analyze the same topic on a broader level by conducting a comparative study in Indonesia and Malaysia. Moreover, the perspectives of government and other actors in facing the issues of terrorism are essential to be analyzed.

\section{ACKNOWLEDGMENT}

This article is the development of authors' research supported by the University of Muhammadiyah Malang, Indonesia, and International Islamic University Malaysia.

\section{AUTHORS CONTRIBUTION}

The first author of this article had responsibility for collecting the data and analyzing the findings. The second writer contributed to the literature review of the article, and the third author is the person in charge of the research methodology and checking the readiness of the article.

\section{REFERENCES}

1. Arifin, Z., \& Rohmah, L. (2019). The concept of leadership of the transnational Islamic ideology perspective and responses to democratic practices in Indonesia. Akademika: Jurnal Pemikiran Islam, 24(1), 213-232. http://dx.doi.org/10.32332/akademika.v24i1.1474

2. Azra, A. (2006). Islam in the Indonesian world: an account of institutional formation. Mizan Pustaka.

3. Baskara, B. (2017). Islamic puritanism movements in Indonesia as transnational movements. DINIKA: Academic Journal of Islamic Studies, 2(1), 1. https://doi.org/10.22515/dinika.v2i1.103

4. Bayman, H. (2003). The secret of Islam: love and law in the religion of ethics (first edition). North Atlantic Books;

5. Brown, L. C. (1984). International Politics and the Middle East: Old Rules, Dangerous Game. I B Tauris \& Co Ltd.https://doi.org/10.1163/2468-1733 shafr_sim220030046

6. Fealy, G. (2004). Islamic radicalism in Indonesia: the faltering revival?Southeast Asian Affairs, 2004, 104-121. https://doi.org/10.1355/9789812306944-010

7. Goodrich, J. N. (2002). September 11th, 2001 attack on America: a record of the immediate impacts and reactions in the USA travel and tourism industry. Tourism Management, 23(6), 573-580. https://doi.org/https://doi.org/10.1016/S0261-5177(02)00029-8

8. Hamilton-Hart, N. (2005). Terrorism in Southeast Asia: expert analysis, myopia, and fantasy. Pacific Review, 18(3), 303-325. https://doi.org/10.1080/09512740500188845

9. Harahap, H. I., Irmayani, T., \& Lubis, F. H. (2019). The rationality of de-radicalization efforts for the children of terrorists at al-hidayah Islamic boarding school. International Journal of Islamic Thought, 16, 38-50. https://doi.org/10.24035/ijit.16.2019.004

10. Jamil, M., Jauhari, I., \& Dahlan. (2019). The response of the pesantren community toward the ideology of Islamism: a study of pesantren teachers' perception in north Sumatra. Journal of Social Studies Education Research, 10(2), 204-223. https://jsser.org/index.php/jsser/article/view/722/376

11. Jones, L. (2016). Explaining the failure of the ASEAN economic community: the primacy of the domestic political economy. Pacific Review, 29(5), 647-670. https://doi.org/10.1080/09512748.2015.1022593

12. Joseph, B., \& Liow, C. (2014). Liow 2014. ISIS goes to Asia: extremism in the middle east isn't only spreading 
west. Foreign Affairsffairs, September, 1-4. https://www.rsis.edu.sg/wpcontent/uploads/2014/09/140921_ISIS_Goes_to_Asia_Foreign_Affairs.pdf

13. Jurdi, S. (2008). Pemikiran politik islam indonesia: pertautan negara, khilafah, masyarakat madani, dan demokrasi. Pustaka Pelajar.

14. Kilcullen, D. J. (2005). Countering global insurgency. Journal of Strategic Studies, 28(4), 597-617. https://doi.org/10.1080/01402390500300956

15. Lim, M. (2011). Radical Islamism in Indonesia and it's middle eastern connections. Middle East Review of International Affairs (Online); Herzliya, https://search.proquest.com/docview/920317892/citation/6B4B4863ADE64B8APQ/1

16. Machmudi, Y. (2008). Islamising Indonesia: the rise of Jemaah tarbiyah and the prosperous justice party (PKS). ANU E Press. https://doi.org/http://doi.org/10.22459/II.11.2008

17. Malik, A. (2017). Stigmatisation of islamic school: pesantren, radicalism and terrorism in bima.Ulumuna, 21(1), 173-210. https://doi.org/10.20414/ujis.v21i1.1159

18. Mubah, A. S. (2012). Teroris versus globalisasi: perlawanan jaringan jamaah islamiyah terhadap hegemoni amerika. Cakra Studi Global Strategis.

19. Oak, G. S. (2010). Jemaah Islamiyah's fifth phase: the many faces of a terrorist group. Studies in Conflict and Terrorism, 33(11), 989-1018. https://doi.org/10.1080/1057610X.2010.514697

20. Omar, I. (2011). Keeping shari'a and reclaiming jihad. Political Theology, 12(5), 706-712. https://doi.org/10.1558/poth.v12i5.706

21. Osman, S. (2010). Jemaah Islamiyah: of kin and kind. Journal of Current Southeast Asian Affairs, 29(2), 157175. https://doi.org/10.1177/186810341002900205

22. Posner, P. L. (2002). Combating terrorism: an intergovernmental partnership in a national strategy to enhance state and local preparedness. General Accounting Office.

23. Sageman, M. (2004). Understanding terror networks. University of Pennsylvania Press. https://doi.org/10.9783/9780812206791

24. Schmid, A. P. (2015). Challenging the Narrative of the Islamic State. ICCT Research Paper, The Hague: International Centre for Counter-Terrorism, 1-19. https://doi.org/10.19165/2015.1.05

25. Sodiq, I., \& Astuti, T. M. P. (2019). Radicalism: the santri pespective in rural java.Advances in Social Science, Education and Humanities Research, 313(ICoRSIA 2018), 67-71. https://doi.org/10.2991/icorsia-18.2019.17

26. Solansky, S. T., \& Beck, T. E. (2009). Understanding interagency collaboration in cyber-terrorism exercises. Administration \& Society, 40(8), 852-875. https://doi.org/10.1177/0095399708326345

27. Sopyan, Y., Syarif, M. I., \& Rais, I. (2019). Measuring human rights and Islamic of Indonesian anti-terrorism law. Ahkam, 19(2), 229-246. https://doi.org/10.15408/ajis.v19i2.13898

28. Sukma, R. (1998). Soft power and public diplomacy: the case of Indonesia. In L. SJ\& M. J (Eds.), Public Diplomacy and Soft Power in East Asia (Issue October 2002, pp. 91-115). Palgrave Macmillan. https://doi.org/https://doi.org/10.1057/9780230118447_6

29. Taufiqurrohman, M. (2015). The road to isis: how Indonesian jihadists travel to Iraq and Syria. Counter Terrorist Trends and Analyses, 7(4), 17-25. www.jstor.org/stable/26351346

30. Tumanggor, R. E. (2007). Indonesia' s counter-terrorism policy. Revista UNISCI, October(15), 87-110. https://www.redalyc.org/pdf/767/76701506.pdf

31. Valbjørn, M., \& Bank, A. (2012). The new Arab cold war: rediscovering the Arab dimension of middle east regional politics. Review of International Studies, 38(1), 3-24. https://doi.org/10.1017/S0260210511000283

32. Vaughn et al, B. (2005). Terrorism in Southeast Asia. http://www.dtic.mil/get-tr-doc/pdf?AD=ADA444939

33. Yumitro, G., Kurniawati, D. E., Saiman, S., \& Haffsari, P. P. (2019). The Modalities and Roles of Pesantren To Face the Issues of Terrorism in the Region of Malang. MIQOT: Jurnal Ilmu-Ilmu Keislaman, 43(1), 95. https://doi.org/10.30821/miqot.v43i1.646 